\title{
Etyczne wyzwania w pracy ze studentami niepełnosprawnymi - perspektywa nauczyciela akademickiego
}

\section{Wprowadzenie}

O niepełnosprawności osób młodych mówi się coraz częściej i na różne sposoby. Zwłaszcza ostatnimi laty, kiedy statystyki prowadzone chociażby przez Główny Urząd Statystyczny wyraźnie wskazują na zwiększającą się populację młodych niepełnosprawnych ${ }^{1}$. Sytuacja komplikuje się jeszcze bardziej, kiedy uświadomimy sobie wewnętrzne zróżnicowanie tej populacji, zwłaszcza pod względem wykształcenia i aktywności zawodowej. O możliwościach rozwojowych w społeczeństwie młodych niepełnosprawnych mówi się najczęściej w kontekście wskazywanych ograniczeń: barier architektonicznych, uwarunkowań środowiskowych, rodzinnych, rzadziej mentalnych; zwłaszcza sprowadzających się do samooceny swego położenia. Czy istniejące stereotypy na temat osób niepełnosprawnych, zwłaszcza młodych, są nadal aktualne? Czy start w dorosłość, poza samą niepełnosprawnością, ma jeszcze

1 Osoby niepełnosprawne w przedziale wiekowym 15-24 lata to niewiele - 4,6 proc., jednakże przy wydłużeniu kryterium wieku do 29 roku życia dane te ulegają podwojeniu. Szerzej: GUS BAEL http://www.stat.gov.pl/gus/5840_2189_PLK_HTML.htm (dostęp: 22.03.2015). 
34 inne uwarunkowania? Na ile zależne są one od środowiska zewnętrznego, na ile stanowią przeszkodę tkwiącą w samej osobie niepełnosprawnej?

\section{Sytuacja osób niepełnosprawnych}

Położenie osób niepełnosprawnych od niemal zawsze nie należy do zadowalających: dostrzega to zarówno społeczeństwo, jak i sami niepełnosprawni. Oficjalne statystyki, rozróżniające osoby z niepełnosprawnościami na mocy prawa oraz niepełnosprawnych biologicznie; zaostrzenie przepisów dotyczących orzekania o niepełnosprawności, a także w kontekście niezdolności do pracy, spowodowały znaczny spadek liczby osób niepełnosprawnych. Jak czytamy w pracy Elżbiety Kryńskiej, spadek osób z niepełnosprawnościami, w sensie prawnym, pomiędzy latami 2002 i 2011 wyniósł prawie 1/3 populacji - z czego na wsi 43 proc. Z kolei w niepełnosprawności biologicznej nastąpił wzrost liczby niepełnosprawnych na wsi - dużo ponad 50 proc., przy jednoczesnym spadku w miastach ${ }^{2}$.

Tymczasem dane statystyczne w ostatnich latach pokazują, że młodych niepełnosprawnych jest stosunkowo mało - ok. 5 proc. (przedział wiekowy 15-24), jednakże przy rozszerzeniu definicji młodej osoby niepełnosprawnej na osoby do 29 roku życia liczba ta ulega podwojeniu ${ }^{3}$. Podejmując zagadnienie społeczności akademickiej, a więc ludzi w młodym wieku, należy podkreślić, że podobnie jak w grupie osób pełnosprawnych - młodzi niepełnosprawni są społecznością wewnętrznie mocno zróżnicowaną, i to w wielu wymiarach. Dotyczy to zwłaszcza podziału ze względu na rodzaje i stopnie niepełnosprawności, dostęp do placówek rehabilitacji, sytuacji rodzinnej, materialnej, wykształcenia czy stopnia aktywności na rynku pracy. Bez względu na sytuację rodzinną czy rodzaj niepełnosprawności osoby niepełnosprawne chcą i funkcjonują na otwartym rynku pracy, jednakże ich obecność jest daleko niezadowalająca. Na ponad dwa miliony niepełnosprawnych w wieku produkcyjnym niecałe pół miliona pracuje. Według danych statystycznych ponad 1/3 osób uważa dyskryminację (zwłaszcza w obszarze zatrudnienia) za jedną z głównych przyczyn takiego stanu rzeczy, z czego dla 29 proc. osób niepełnosprawność jest główną przyczyną odrzucenia

2 Analiza sytuacji osób niepełnosprawnych w Polsce i Unii Europejskiej. Raport przygotowany w ramach projektu „Zatrudnienie osób niepełnosprawnych - perspektywy wzrostu”, red. E. Kryńska, Warszawa 2013, s. 7.

3 GUSBAEL http://www.stat.gov.pl/gus/5840_2189_PLK_HTML.htm (dostęp: 12.05.2015). 
potencjalnego kandydata z listy rekrutacyjnej do zatrudnienia ${ }^{4}$. Wielokrotnie słyszy się, że powodem nieprawidłowych lub wręcz wrogich relacji pomiędzy społecznością sprawnych i niepełnosprawnych osób są - nadal silnie zakorzenione - stereotypy, a w przypadku pracodawców bardzo słaba wiedza i znajomość prawa. Brak akceptacji dla odmienności przejawia się nie tylko w agresji, obojętności, ale i w czymś odwrotnym - próbach zagłuszenia swoich obaw i poczucia zagrożenia - dochodzi do okazywania czułości, które mogą się przeobrazić w nadopiekuńczość. Z jednej strony deklarujemy swoje współczucie i chęć pomagania, ale z drugiej strony wolimy, kiedy ktoś w tym wspieraniu nas wyręcza ${ }^{5}$. Nadal silnie obecne w przestrzeni publicznej jest postrzeganie osób niepełnosprawnych w kategorii „innych”, a więc nieznanych, wzbudzających nieuzasadniony niepokój. Człowiek boi się ludzi czy sytuacji, wobec których nie wie, jak postępować. Ale także sami niepełnosprawni mają obawy w stosunku do środowiska pełnosprawnych, w którym przychodzi im żyć i podejmować codzienne aktywności. Nie są pewni przyjaznych zachowań, akceptacji ich odmienności, zwłaszcza kiedy ich wygląd zewnętrzny dalece odbiega od ogólnie przyjętego (różne deformacje kończyn, twarzy itp.). Najczęstszą reakcją obronną jest pozostanie w przysłowiowych czterech ścianach, świadoma izolacja, zwłaszcza w małych środowiskach wiejskich.

Jak na tym tle przedstawia się sytuacja edukacyjna dzieci i młodzieży z niepełnosprawnościami? Jeszcze niedawno podejście do kształcenia dzieci ze specjalnymi potrzebami sprowadzało się do systemu edukacyjno-segregacyjnego, w którym powstawały szkoły specjalne, gdzie na osoby niepełnosprawne patrzono przez pryzmat ich choroby, ograniczeń - zarówno fizycznych, jak i psychicznych. W pierwszym rzędzie przygotowywano ich do przyszłej pracy zawodowej, co skutkowało wypracowaniem specjalnego systemu spółdzielni inwalidów, w których przystosowywano stanowiska i rodzaj wykonywanej pracy do stopnia i rodzaju niepełnosprawności ${ }^{6}$.

Obecnie możliwości edukacyjne dzieci i młodzieży są mocno zróżnicowane, jednak nadal dostępność edukacji jest większa w dużych aglomera-

4 http://www.niepelnosprawni.gov.pl; http://www.kartaroznorodnosci.pl/pl/aktualnosci. html?id=113 (dostęp: 10.05.2015).

5 http://www.nasz-cel.pl/publikacje/324-postawy-ludzi-penosprawnych-wobecniepenosprawnych (dostęp: 10.05.2015).

6 http://www.abcd.edu.pl/index.php?option=com_content\&view=article\&id=26:psycho spoleczne-aspekty-edukacji-niepelnosprawnych-dzieci-oraz-mlodziezy-\&catid=14: edukacja-wlaczajaca\&Itemid=28 (dostęp: 2.05.2015). 
36 cjach miejskich, mniejsza i uboższa oferta dotyczy miejscowości małych lub odległych od centrów miejskich. Jednakże sprowadzenie trudności tylko do miejsca zamieszkania byłoby daleko idącym uproszczeniem. Zjawisko to jest uwarunkowane także innymi determinantami, wśród których należy wskazać: sytuację bytową, uwarunkowania kulturowe, stan świadomości rodziców i najbliższego środowiska zamieszkania w aspekcie niepełnosprawności dziecka; znajomość jego potrzeb czy ogólną sytuację społeczno-polityczną państwa. Na szczególne podkreślenie zasługuje przypomnienie, iż istniejący do niedawna system edukacyjny osób niepełnosprawnych sprowadzał się, de facto, do tworzenia społecznej, mentalnej bariery pomiędzy dwoma światami: pełnosprawnych i niepełnosprawnych. O trudnościach, potrzebach, smutkach i radościach tych ostatnich wiedziało grono rodzinne i nieliczni znajomi. Wprowadzenie w rzeczywistość polityczno-społeczną tzw. strategii włączania (koncepcja disablity mainstreaming), także w odniesieniu do osób zagrożonych izolacją czy rzeczywistym wykluczeniem społecznym, powoli zaczęło przynosić oczekiwane rezultaty.

\section{Rzeczywistość edukacyjna}

Wprowadzenie do rzeczywistości edukacyjnej integracyjnych oddziałów przedszkolnych, szkół integracyjnych czy szkół z klasami integracyjnymi powoli zaczęło zmieniać sytuację dzieci i młodzieży na lepsze. Wytworzyła się konieczność przygotowania indywidualnych programów dla wszystkich uczniów w klasie, bez względu na stan sprawności; możliwość poznawania się uczniów nawzajem - „swoich” dotychczas odmiennych „światów”, a wszystko po to, by przygotować ich na dorosłość, która bywa - dla obu grup - nieprzychylna, a czasami nawet wroga. Obecność pełnosprawnych rówieśników motywuje uczniów niepełnosprawnych do podjęcia wysiłków edukacyjnych, rozbudza marzenia, nadaje sens ich działaniom ${ }^{7}$. Postępujące zmiany potwierdzają opracowania statystyczne. I tak koniec ubiegłego wieku wykazywał, iż wskaźnik osób studiujących oscylował w okolicy 0,08 proc., a po przeszło dekadzie wyniósł już 1,71 proc. $^{8}$. Mimo zwiększającej się liczby niepełnosprawnych podwyższających swoje wykształcenie dystans

7 Szerzej: Integracja dzieci niepełnosprawnych w przedszkolu i szkole: (raporty z badań), red. M. Apolinarska, Warszawa 1994.

8 Podaję za: M. Racław, Niepełnosprawni absolwenci szkół wyższych. Potencjał, który staje się problemem instytucji, www.polscyniepelnosprawni.agh.edu.pl (dostęp: 10.05.2015). 
w stosunku do ogólnej liczby wykształconych rówieśników nie zmniejsza się. Niemniej należy podkreślić, że po przystąpieniu Polski do Unii Europejskiej, po dostosowaniu przepisów państwowych sytuacja osób niepełnosprawnych polepszyła się, co znalazło przełożenie w zwiększonym dostępie do ofert otwartego rynku pracy.

Dzięki reformie szkolnictwa wyższego w 2011 roku uczelnie wyższe zyskały możliwości wspierania przyszłych studentów niepełnosprawnych zwiększyły się możliwości udziału w procesie kształcenia, ale również możliwości prowadzenia badań naukowych dla studentów studiów III stopnia (doktoranckich) ${ }^{9}$. Uczelnie zaczęły otrzymywać dotacje finansowe na m.in. „specjalistyczne szkolenia, wyposażenie wypożyczalni sprzętu dla niepełnosprawnych, zakup specjalistycznych urządzeń, materiałów dydaktycznych i naukowych dostosowanych do potrzeb niepełnosprawnych czy transport między obiektami dydaktycznymi uczelni"10. Nadto studenci mogą otrzymywać stypendia specjalne, ale także mogą korzystać z pozostałych możliwych form wsparcia, które są dostępne dla ogólnej społeczności akademickiej (stypendia socjalne, rektora, ministra czy inne, np. branżowe). Także dla studentów niepełnosprawnych dostępne są kredyty bankowe, przeznaczone na pokrycie kosztów nauki, z preferencyjnymi warunkami spłaty.

Badania nad studentami niepełnosprawnymi prowadzone w wybranych uczelniach pozwoliły na zweryfikowanie dotychczasowej wiedzy. Co wydaje się oczywiste, „kariera edukacyjna” respondentów odbiegała od funkcjonującego stereotypu. Nie doszliby tak daleko, gdyby myśleli o sobie w kategorii „gorszych”, „mniej przydatnych”; gdyby nie wzrastali w środowisku, które traktowało ich jak „pełnosprawnych”. Pomimo dotychczasowych doświadczeń czas studiów okazał się źródłem zdobycia dodatkowych relacji, dostępu do wiedzy, poznania możliwości samorealizacji itp. Jednakże czas ten pokazał także szereg niedociągnięć w systemie wspierania studentów niepełnosprawnych, ale i prawdę, że - mimo wielu przeobrażeń - mentalna strona postrzegania osób niepełnosprawnych, zwłaszcza na rynku pracy, ulega daleko powolniejszym zmianom ${ }^{11}$. Odnosi się wrażenie, że myśląc

9 http://www.nauka.gov.pl/wsparcie-niepelnosprawnych-studentow-i-doktorantow/ (dostęp: 15.05.2015).

10 http://www.nauka.gov.pl/wsparcie-niepelnosprawnych-studentow-i-doktorantow/ (dostęp: 15.05.2015).

11 E. Giermanowska i in., Niedokończona emancypacja. Wejście niepełnosprawnych absolwentów szkół wyższych na rynek pracy, Warszawa 2015, www.polscyniepelnosprawni.agh. edu.pl (dostęp: 10.05.2015). 
38 o programach wspierających, nie ma się całościowej wizji - w każdym razie nie we wszystkich środowiskach takie myślenie ma miejsce. Tak więc nadal miejsce zamieszkania ma ogromny wpływ na ścieżki karier edukacyjnych i zawodowych. Istotna okazała się metoda pracy w środowisku i jego uwrażliwienie na potrzeby osób niepełnosprawnych. Współpraca osoby niepełnosprawnej, jej rodziny i środowiska lokalnego pozwala na szybkie i - co ważne - trafne reagowanie na zmieniające się potrzeby i oczekiwania. Wbrew powszechnej opinii młodzi niepełnosprawni - oczywiście w zależności od stopnia zależności - nie oczekują dostępnych pasywnych form wspierających. Wolą wsparcie umożliwiające podjęcie aktywności w celu osiągnięcia wyznaczonych, wymarzonych celów.

Tym, co niewątpliwie frustruje młodych niepełnosprawnych, zwłaszcza studiujących, jest słaby wskaźnik zatrudnienia. Okazuje się, że oczywiście wyższe wykształcenie poszerza horyzonty, podnosi kwalifikacje, ale nie znajduje prostego przełożenia na znalezienie pierwszej pracy. Stan ten odzwierciedla ogólną sytuację młodych na otwartym rynku pracy. Dane Eurostatu pokazują, że w większości krajów europejskich utrzymuje się spadkowa tendencja zatrudnieniowa w populacji niepełnosprawnych $\mathrm{z}$ wyższym wykształceniem. Także sporo frustracji przeżywają młodzi w związku z zatrudnieniem na tzw. umowach śmieciowych. Brak poczucia stabilności w tym zakresie skutkuje dalszymi decyzjami życiowymi, np. odkładaniem decyzji o założeniu rodziny, urodzeniu pierwszego dziecka czy budowaniem dalszej perspektywy - tak zawodowej, jak i rodzinnej ${ }^{12}$.

\section{Perspektywa środowiska akademickiego}

Przedstawione powyżej rozważania stanowią z konieczności ograniczone w opisie tło dla rozważań nad wyzwaniami, jakie współczesność stawia przed nauczycielami wszystkich szczebli drabiny edukacyjnej: zwłaszcza w kontekście wymogów „kształcenia przez całe życie”. Bez względu na szczebel edukacyjny istnieje konieczność posiadania odpowiedniego przygotowania w tym zakresie. Mówiąc o środowisku akademickim, należy podkreślić, że nie chodzi tutaj tylko o właściwe przygotowanie w obszarze pedagogiki specjalnej. Wiele zależy od odpowiedzi na pytanie, czy posiadane wykształcenie pozwala mi na prowadzenie zajęć także ze studentami niepełnosprawnymi? 
Po drugie, czy znam zasady etyczne zawodu nauczyciela akademickiego oraz czy stosuję je w codziennej pracy zawodowej?

Nieustannie toczy się dyskusja o zasadności i możliwości stosowania etyk zawodowych. Obawy dotyczą zarówno argumentów o możliwości nadmiernego relatywizowania wartości i norm moralnych, jak również przerostu aspektu prakseologicznego nad aksjologicznym ${ }^{13}$. Oczywistym jest, że powyższe obawy nie stanowią tylko czysto akademickich dyskusji i należy je brać pod uwagę, jednakże istota rzeczy sprowadza się do człowieka - ucznia studenta, szacunku dla jego godności; działania w prawdzie, dla dobra wspólnego - w poczuciu odpowiedzialności za własne słowa i czyny.

Zadane powyżej pytania dotyczą etyki w aspekcie odpowiedzialności moralnej, w stosunku do społeczności akademickiej, przez które rozumie się zarówno studentów, jak i wykładowców.

Odniesienie do studentów, podobnie jak do pozostałych grup, musi cechować się obiektywnością, sprawiedliwością, rzetelnością, wysokim przygotowaniem merytorycznym, ale nade wszystko - wrażliwością na sytuację osób niepełnosprawnych. Dotyczy to zarówno przekazywanej wiedzy, sposobu i kryteriów jej oceniania, jak i bycia elastycznym w swych wymaganiach. Przytoczone statystyki pokazują, że zwiększa się liczba studiujących niepełnosprawnych. To cieszy, ale jednocześnie napawa niepokojem o stopień przygotowania kadry dydaktycznej do pracy z grupą wewnętrznie zróżnicowaną. Działające od kilkunastu lat na polskich uczelniach biura ds. osób niepełnosprawnych (skrót: BON) prowadzą szeroką politykę informacyjną, przybliżając z jednej strony wiedzę o możliwościach i potrzebach niepełnosprawnych studentów, a jednocześnie starając się spełniać ich oczekiwania w stosunku do wykładowców i rówieśników. Organizowane są szkolenia, na których kadra akademicka może rozszerzyć swoją wiedzę na temat najczęstszych niepełnosprawności, oraz warsztaty, podczas których można zdobyć konkretną wiedzę, jak pracować ze studentami niepełnosprawnymi. Istotna jest świadomość, że osoba niepełnosprawna to nie „inny człowiek”, a jej schorzenie nie musi oznaczać innego, „specjalnego” traktowania (tutaj: tzw. taryfy ulgowej). Tak więc punktem wyjścia jest nieustanne wzbogacanie wiedzy na temat zjawisk, które składają się na sam proces dydaktyczny, na możliwości przyswajania wiedzy przez studentów. Dzisiaj pomaga w tym polityka prowadzona na poszczególnych uczelniach wyższych - polityka

13 B.Dziemidok, Etyka zawodu nauczyciela akademickiego, www.studiagdanskie.gwsh.gda.pl/ pdfy/studia4-14.pdf (dostęp: 21.05.2015). 
40 wyrównywania szans. Jest ona możliwa po prawidłowo przeprowadzonej diagnozie potrzeb studentów niepełnosprawnych. Na stronach internetowych wielu biur ds. osób niepełnosprawnych można znaleźć informacje - dla całej społeczności akademickiej - o potrzebach studentów z różnymi niepełnosprawnościami oraz dostępnych możliwościach wsparcia. Znajomość potrzeb pozwala we właściwy sposób organizować życie akademickie tych osób. Wędrując po stronach internetowych uczelni akademickich, nie sposób jednak nie odnieść wrażenia, że informacje o niepełnosprawnościach zamykają się w dość hermetycznym kręgu stereotypowego postrzegania niepełnosprawnych ruchowo, z niedoborami słuchu i niesłyszących, z zaburzeniami widzenia i niewidomych czy zaburzonych psychicznie ${ }^{14}$. A przecież istnieją także inne, chociażby choroby neurologiczne, układu oddechowego i krążenia, moczowo-płciowego czy schorzenia metaboliczne ${ }^{15}$. Dolegliwości z nimi związane mogą być niewidoczne, o nasileniu okresowym. Dlatego tak ważna jest rola rzeczników czy pełnomocników ds. osób niepełnosprawnych na uczelniach, by prowadzić bieżącą politykę, informując prowadzących zajęcia na poszczególnych grupach o studentach niepełnosprawnych i ich specyficznych potrzebach. Należy podkreślić, że ich niedomagania nie wymagają odstępstw od przyjętych warunków zaliczenia - częściej sprowadzają się do zmiany formy czy czasu podejścia do zaliczeń czy egzaminów. Sami studenci niepełnosprawni nie chcą i nie oczekują traktowania ulgowego - są ambitni w swych działaniach i starają się sprostać ogólnie obowiązującym wymaganiom. Oczywiście, może się zdążyć i tak, że pojawią się jednostki, które postawę roszczeniową mają niemal od urodzenia i ich negatywne przejawy znajdą odzwierciedlenie w życiu akademickim. Jednakże, jak podkreślają pracownicy BON-ów, są one coraz rzadsze.

Istniejące kodeksy etyczne nauczycieli akademickich wyraźnie akcentują wzajemną współprace, szacunek i wymianę doświadczeń jako jedne z możliwości dobrej współpracy na rzecz społeczności danej uczelni. A więc odnosi się to także do grupy studentów niepełnosprawnych. Należy zwrócić uwagę na ważny element pracy nauczyciela akademickiego - na jego pracę wychowawczą. Ma się wrażenie, że tę umiejętność mają tylko nieliczni. Uwaga ta odnosi się zwłaszcza do profesorów czy adiunktów, którzy prowadzą wykłady

14 Porównaj chociażby informacje zamieszczone na stronie Biura ds. Osób Niepełnosprawnych Uniwersytetu Warszawskiego, http://www.bon.uw.edu.pl/studiujemy_razem.html (dostęp: 21.05.2015).

15 Szerzej: http://www.niepelnosprawni.pl/ledge/x/203749;jsessionid=99C54BD0AE5D 35F49D4EOFC6AAABF910 (dostęp: 26.06.2015). 
w dużych grupach; kontakt osobisty jest możliwy dopiero w małych grupach seminaryjnych, a o znaczeniu kontaktów osobistych i budowaniu postawy wzajemnego zaufania, gdzie profesor stawał się często mentorem studenta, pisali już starożytni. Współcześni „akademicy” często nie odczuwają potrzeby podejmowania takich działań, co jest znaczące w kontaktach ze studentami o zmniejszonych możliwościach fizycznych czy psychicznych. Ich dobre wyniki w nauce czy późniejszej działalności naukowej okupione są ogromnym wysiłkiem i nakładem pracy. Jak dużym - można się przekonać właśnie w relacjach interpersonalnych, często pozaformalnych.

Pozostaje indywidualne pochylenie się nad problematyką niepełnosprawności. Bez względu na podejmowane pogramy wspierające i wyrównujące szanse studentów niepełnosprawnych sukces podejmowanych działań zależy od chęci i możliwości samego wykładowcy, nauczyciela akademickiego. Uzmysłowienie sobie swoich niedoborów w temacie niepełnosprawności, może istniejących uprzedzeń czy niechęci - to podstawa skutecznej współpracy na rzecz osób nie w pełni sprawnych i z tymi osobami. Nasza postawa otwartości na to, co nowe i nieznane - a winna być ona dana każdemu nauczycielowi akademickiemu - z jednej strony pozwoli na konieczne uzupełnienie braków w stosownej tematyce, a z drugiej pokaże studentom, że problemem nie jest brak wiedzy, ale niechęć do jej uzupełnienia, co często przejawia się postawą ignorancji i lekceważenia. I dotyczy nie tylko osób niepełnosprawnych. Kolejną kwestią, istotną dla podjętej problematyki, jest zdolność słuchania, co często jest trudnym u osób przyzwyczajonych do przekazywania wiedzy - nauczania innych. Chcemy, by nas słuchano, rzadziej sami potrafimy słuchać. Jednakże, zwłaszcza w odniesieniu do osób z niepełnosprawnościami, jest to umiejętność niezwykle przydatna, cenna. My nie musimy wiedzieć, jak pomagać, co utrudnia przyswojenie danej partii materiału i może opóźnić np. podejście do sesji egzaminacyjnej w wyznaczonym terminie. Jednakże zadanie pytania osobie bezpośrednio zainteresowanej jest najlepszym rozwiązaniem. Student niepełnosprawny nie odbierze tego jak kolejnej uciążliwości, wręcz odwrotnie - zobaczy, że jesteśmy rzeczywiście zainteresowani jego osobą i zależy nam na jego wynikach. Sam niepełnosprawny najlepiej nas pokieruje i pokaże, jak skutecznie go wesprzeć, traktując jednocześnie na równi z innymi, pełnosprawnymi ${ }^{16}$. Życzliwość

16 Uniwersytet Śląski w Katowicach, Savoir-vivre wobec osób niepełnosprawnych, http://stu dent.us.edu.pl/files/student/pdf/SAVOIR-VIVRE\%20wobec\%20os\%C3\%B3b\%20niepe \%C5\%82nosprawnych.pdf (dostęp: 23.05.2015). 
42 i takt to kolejne cechy nauczyciela akademickiego. Należy jeszcze wyróżnić umiejętność dotrzymanie tajemnicy. To niezwykle istotny wymóg każdej grupy zawodowej, ale w szczególności zawodów tzw. wsparcia społecznego, do których zawód nauczyciela niewątpliwie należy. Powierzana nam wiedza na temat stanu zdrowia drugiej osoby to $\mathrm{z}$ jednej strony ogromne zaufanie, a z drugiej - ogromna odpowiedzialność, jaka została na nas nałożona. Jedyna możliwa odpowiedź z naszej strony to dochowanie tajemnicy. Z przedstawionych powyżej wskazań, istotnych dla relacji z osobą niepełnosprawną, a zawartych w akademickim savoire-vivrze, przytoczę jeden fragment, który może stanowić podsumowanie dla działań etycznych w środowisku nauczycieli akademickich: „Zachowania uniwersalne: 1. Zanim udzielisz pomocy zapytaj! 2. Bądź taktowny i tolerancyjny. 3. Nie podejmuj decyzji za innych. 4. Jeśli możesz - spełnij prośbę. Skoncentruj się na osobie, a nie na jej niepełnosprawności!"17. I to ostatnie zdanie pokazuje, na czym polega mechanizm podejścia do odmienności, bo przecież każdy z nas jest niepowtarzalny w swej istocie - bez względu na to, czy jest pełnosprawny, czy niepełnosprawny; czy różni się od nas poglądami, kolorem skóry czy językiem. Odmienności nie powinny stanowić bariery dla porozumiewania się, wręcz przeciwnie mogą stanowić swoistą kopalnię informacji o tym, co upodabnia nas do siebie - różnice przyciągają się, a nie odpychają, jak mówi jedno z powiedzeń.

\section{Podsumowanie}

Etyka w działalności nauczyciela akademickiego, zwłaszcza w odniesieniu do studentów niepełnosprawnych, pozostaje poza wszelką dyskusją. Poza moralnością obowiązującą $\mathrm{w}$ danej społeczności pozostaje szereg takich zjawisk, których nie sposób przewidzieć, a w stosunku do których winniśmy wypracować sposoby reagowania, zachowania, często w sposób niekonwencjonalny, bo uwzględniający możliwości odstępstw od dotychczas znanych rozwiązań. Co więcej, zawód nauczyciela jest jednym z tych, w stosunku do którego stosuje się kryteria maksymalistyczne dotyczące rozwiązań moralnych. Tymczasem pojawiają się nowe, w stosunku do których rozwiązania zawarte w kodeksach są niewystarczające lub w ogóle ich brak. Jednocześnie nasuwa się tutaj istotne pytanie: czy wolno mi stosować odstępstwa w zakresie moralności, bo inni tak robili? Na ile jest to zgodne z moim systemem

17 Uniwersytet Śląski w Katowicach, Savoir-vivre wobec osób niepełnosprawnych, dz. cyt. 
norm i wartości? Czy moje zachowanie nie podważy statusu zawodu nauczy-

ciela akademickiego, jego dobrego imienia? Oczywiście, można powiedzieć, że na co dzień wielu lekarzy czy prawników musi odpowiedzieć sobie na takie pytanie i nie zawsze ich odpowiedzi są tymi właściwymi. To jednak absolutnie nie upoważnia nas do podejmowania podobnych wyborów. Praca z człowiekiem, kształtowanie jego osobowości, jej rozwój to nie praca z materią nieożywioną. Tutaj każdy popełniony błąd skutkuje poranieniem konkretnej osoby, którą życie już dostatecznie doświadczyło. Czy jesteśmy uprawnieni do przeprowadzania takich eksperymentów?

Jak ktoś kiedyś powiedział, niepełnosprawność to zranione człowieczeństwo i mimo że jest to problem społeczny, nie można zapominać, że dotyczy pojedynczego człowieka i domaga się poszanowania jego godności. Każda z niepełnosprawnych osób ma potrzebę życia, a więc pragnie być człowiekiem wolnym, niezależnym; chce się rozwijać i spełniać marzenia. Chce żyć w poczuciu bycia akceptowanym, nie ze względu na swoje ułomności, ale na fakt wartości bycia człowiekiem. Chce, by ją rozumiano, kochano i by sama mogła kochać. To tylko niektóre „postulaty”, jakie w stronę społeczeństwa „sprawnych” kieruje Jean Vanier, kanadyjski działacz i filantrop, organizator pomocy dla osób niepełnosprawnych intelektualnie, założyciel wspólnot L'Arche) ${ }^{18}$.

Poczucie świadomości, że jesteśmy - jak mało kto - przeznaczeni do towarzyszenia niepełnosprawnym studentom na kolejnym etapie ich życia, jakim są studia, winno napawać nas dumą. Ważne jest, by pamiętać, że nie jest to koniec ich wędrowania, ale etap w drodze do czegoś więcej, do budowania ich przyszłości. Fakt, iż możemy mieć udział w ich radości z pokonywania towarzyszących im ułomności, winien napawać nas optymizmem. Wyzwaniem jest, by odcisnąć na nich swe piętno nie jako uczeń czy czeladnik - od nauczyciela domaga się postawy mistrza.

\section{Ethical challenges in work with students with disabilities - academic teacher's perspective}

For a good few years, much is said about people with disabilities and a variety of programs to support these people in their deficiencies. This also applies to the academic

18 J. Vanier, Wspólnota. Wybór pism, tłum. zespół pod red. M. Przeciszewskiego, Warszawa 1985, s. 104-105. 
44 community. But do their efforts can meet the needs of these people? Is their quality of life actually depends only on material goods? These and similar questions are the basis for discussion in this article.

Keywords: disability, the academic community, ethics

\section{Etyczne wyzwania w pracy ze studentami niepełnosprawnymi - perspektywa nauczyciela akademickiego}

Od dobrych kilku lat wiele mówi się o osobach niepełnosprawnych i różnorodnych programach mających wspierać te osoby w ich niedoborach. Odnosi się to także do społeczności akademickiej. Czy jednak podejmowane starania mogą sprostać potrzebom tych osób? Czy ich jakość życia rzeczywiście zależy tylko od dóbr materialnych? Te i podobne pytania stanowią podstawę do rozważań zawartych w poniższym artykule.

Słowa kluczowe: niepełnosprawność, społeczność akademicka, etyka

\section{Bibliografia}

Analiza sytuacji osób niepełnosprawnych w Polsce i Unii Europejskiej. Raport przygotowany w ramach projektu „Zatrudnienie osób niepełnosprawnych - perspektywy wzrostu”, red. E. Kryńska, Warszawa 2013.

Dziemidok B., Etyka zawodu nauczyciela akademickiego, www.studiagdanskie.gwsh.gda. pl/pdfy/studia4-14.pdf (dostęp: 21.05.2015).

Giermanowska E. i in., Niedokończona emancypacja. Wejście niepełnosprawnych absolwentów szkół wyższych na rynek pracy, Warszawa 2015, www.polscyniepelnosprawni. agh.edu.pl (dostęp: 10.05.2015).

GUS BAEL http://www.stat.gov.pl/gus/5840_2189_PLK_HTML.htm (dostęp: 12.05.2015).

http://rynekpracy.org/wiadomosc/671643.html (dostęp: 21.05.2015).

http://www.abcd.edu.pl/index.php?option=com_content\&view=article\&id=26:psy chospoleczne-aspektyedukacji-niepelnosprawnych-dzieci-oraz-mlodziezy-\& catid=14:edukacja-wlaczajaca\&ltemid=28 (dostęp: 2.05.2015).

http://www.nasz-cel.pl/publikacje/324-postawy-ludzi-penosprawnych-wobecniepenosprawnych (dostęp: 10.05.2015).

http://www.nauka.gov.pl/wsparcie-niepelnosprawnych-studentow-i-doktorantow/ (dostęp: 15.05.2015).

http://www.niepelnosprawni.gov.pl; http://www.kartaroznorodnosci.pl/pl/aktualno sci.html?id=113 (dostęp: 10.05.2015). 
http://www.niepelnosprawni.pl/ledge/x/203749;jsessionid=99C54BD0AE5D3 5F49D4EOFC6AAABF910 (dostęp: 26.06.2015).

Integracja dzieci niepełnosprawnych w przedszkolu i szkole: (raporty z badań), red. M. Apolinarska, Warszawa 1994.

Racław M., Niepełnosprawni absolwenci szkół wyższych. Potencjał, który staje się problemem instytucji, www.polscyniepelnosprawni.agh.edu.pl (dostęp: 10.05.2015).

Uniwersytet Śląski w Katowicach, Savoir-vivre wobec osób niepełnosprawnych, http:// student.us.edu.pl/files/student/pdf/SAVOIRVIVRE\%20wobec\%20os\%C3\%B3 b\%20niepe\%C5\%82nosprawnych.pdf (dostęp: 23.05.2015).

Vanier J., Wspólnota. Wybór pism, tłum. zespół pod red. M. Przeciszewskiego, Warszawa 1985. 